\title{
LEARNING FROM THE FALLS (TÚATH NA BHFÁL) AND BOMBAY STREET PROJECT (ARCHITECT SEÁN MACKEL), BELFAST: URBAN REFLECTIONS FROM THE MOST DIVIDED AND RESILIENT STREETS IN WESTERN EUROPE
}

\author{
Alona Martínez Pérez \\ Leicester, United Kingdom \\ alona.martinezperez@dmu.ac.uk
}

De Montfort University, Architecture Design and Humanities, Leicester School of Architecture,

\begin{abstract}
This paper examines the Falls Road (located in West Belfast) which is a largely Catholic/Irish Republican neighbourhood particularly relevant during the conflict known as The Troubles, which affected Northern Ireland for some forty years from the late 1960s until 1998. During this period and to this day, Falls Road became the heart of Irish republicanism and the most divided street in Western Europe. The human cost of the conflict was more than 3,500 dead. On the other side of the wall is the other street, the Shankhill Road (Protestant and Unionist). This gives a clear picture of the impact of the conflict in the context of street life before The Troubles began. The Falls Road in West Belfast, which runs from Divis Street to Andersonstown, derives from the expression túath na bhFál, which in Irish means "territory of the enclosures". I have worked as an architect and
\end{abstract}

researcher for over a decade in the city on both sides of the wall. This paper examines the typology of the divided street and its transition into a successful example of Irish renaissance culture and urban regeneration. The paper is divided into two parts in which the Falls Strip will be dissected:1x The Falls (lower part of the street), 2-Bombay Street (architect Seán Mackel). I will use Manuel de Solà-Morales' approach to the construction of this street in Belfast as an "urban city of conflict", as a succession of episodes, data, dates, facts, details and events and interpretations and the opening of the street in this case to understand the lessons that can be drawn from a clear typological study of the street in two sections.

Key words: divided cities, conflict cities, Irish cities, Belfast regeneration. Bombay Street, Seán Mackel 


\section{RESUMEN}

Se estudiará aquí Falls Road (situado en el oeste de Belfast) que es un barrio mayoritariamente católico/republicano irlandés especialmente relevante durante el conflicto conocido como The Troubles, que afectó a Irlanda del Norte durante unos cuarenta años, desde finales de la década de 1960 hasta 1998. Durante este periodo y hasta hoy, Falls Road se convirtió en el corazón del republicanismo irlandés y en la calle más dividida de Europa Occidental. El coste humano del conflicto superó en más de 3.500 muertos. Al otro lado del muro se encuentra la otra calle, la Shankhill Road (protestante y unionista). Esto da una idea clara del impacto del conflicto en el contexto de la vida en la calle antes de que comenzaran The Troubles. La Falls Road, en el oeste de Belfast, que va desde la calle Divis hasta Andersonstown, deriva de la expresión túath na bhFál, que en irlandés significa "territorio de los cercados". He trabajado como arquitecta e investigadora durante más de una década en la ciudad a ambos lados del muro. Este artículo examina la tipología de la calle dividida y su transición a un ejemplo exitoso de la cultura del renacimiento irlandés y la regeneración urbana. La ponencia está dividida en dos partes en las que se diseccionará la Franja de las Cataratas:1- Las Cataratas (parte baja de la ca1le), 2-Bombay Street (arquitecto Seán Mackel). Utilizaré el enfoque de Manuel de Solà-Morales para la construcción de esta calle en Belfast como una "ciudad urbana de conflicto", como una sucesión de episodios, datos, fechas, hechos, detalles y eventos e interpretaciones y la apertura de la calle en este caso para entender las lecciones que se pueden extraer de un claro estudio tipológico de la calle en dos secciones.

\section{Palabras clave: ciudades divididas, ciudades en conflicto, ciudades irlandesas, regenera- ción de Belfast, calle Bombay, Seán Mackel}

\section{RESUMO}

O artigo estuda Falls Road (localizada em West Belfast), bairro irlandês predominantemente católico/republicano, durante os conflitos conhecidos como The Troubles, os quais afetaram a Irlanda do Norte por cerca de quarenta anos, desde o final dos anos 60 até 1998. Durante este período, e até hoje, Falls Road tornou-se o coração do republicanismo irlandês, a rua mais dividida da Europa Ocidental. O custo humano do conflito superou 3.500 mortes. Do outro lado do muro localiza-se Shankhill Street, rua protestante e unionista. Esta descrição dá uma ideia do impacto do conflito no contexto da vida nas ruas, antes do início de The Troubles. Falls Road em West Belfast, que vai da Divis Street até Andersonstown, deriva da frase túath na bhFál que em irlandês significa "território dos recintos". Como arquiteta e pesquisadora, por mais de uma década tenho investigado a cidade em ambos os lados do muro. Este trabalho analisa a tipologia da rua dividida e sua transição para um exemplo de sucesso da cultura irlandesa de revitalização e regeneração urbana. O trabalho está dividido em duas partes nas quais a Falls Strip será dissecada: 1- The Falls, a parte inferior da rua; 2-Bombay Street (arquiteto Seán Mackel). Será empregada a abordagem de "cidade urbana do conflito", de Manuel de Solà-Morales, para a construção desta rua em Belfast como uma sucessão de episódios, dados, datas, fatos, detalhes e eventos, assim como interpretações e a abertura da rua para entender as lições decorrentes de um estudo tipológico da rua em duas secções. 
Palavras-chave: cidades divididas, cidades em conflito, cidades irlandesas, regeneração de Belfast, rua Bombay, Seán Mackel

\section{INTRODUCTION}

To analyse the Falls as a typology of a divided street, an immersive method has been adopted, by walking and photographing the two sections of the street - based on the author's methodological previous experience analysing urban peripheries (Martínez Pérez 2016). Urban episodes of the conflict will be referred to in each section of the street and analysed, along with its impact on the street fabric over 35 years of conflict, using a theoretical mixed approach using Aldo Rossi's concept of urban artifacts as a concept for this purpose and the idea of memory. Returning to Manuel de Solà-Morales by way of superposed models describing the construction of Barcelona, I will use this approach for the construction of this street in Belfast as an "urban city of conflict" and the seminal book Learning from Las Vegas I will use the idea of Strip as an urban entity that could let us know how the typology of this urban strip has developed from the late 1960's to today (using mainly the Studio Notes from the book as a method as explained before). As mentioned, I have worked full time in Belfast as an architect/researcher for four years, and over twelve years overall on both sides of the wall, and both communities (Catholic/Protestant) knowing the ground very well and understanding the sensitive nature of this urban context and the communities living in these areas. As a researcher, I look at these factors independently and in an equal manner, however as this paper concentrates mainly in a Catholic enclave in West Belfast (Northern Ireland). Most of the factors and devices relate to the Catholic/Irish community in this instance. Lessons and reflections, however, can be applied to both sides of the community.

For the purpose of this paper, I will cover key dates and factors from both the Conflict and the Troubles, that led to the creation of urban devices, such as peace lines, Westlink, security etc. I believe as a researcher/architect, it is important to discuss the resultant issues (from an urban perspective) due to the conflict, particularly 40 years after the Troubles started, and 25 years after the Good Friday Agreement so we can learn from the recent past and move forward towards a common urban future in Northern Ireland.

Many of these devices were created as temporary devices at the beginning of the conflict but have now become permanent in the city's landscape. The conflict created certain factors and events, that lead to the building of devices and urban structures that lead to division, and by still being in the city's landscape today, will not contribute to lessen these divisions. To assist in analysis of these issues, I will refer to archival research of early period of the Troubles, a Working Paper that was created in 1971, it was meant to be Secret and only 52 copies were made. The Document is titled "Government of Northern Ireland Future Policy on Areas of Confrontation. Second and Final Report of the Joint Working Party on Processions, etc", I had a PDF copy number 43 (out of the 52 copies that were made) of the Document provided to me by the Belfast Interface Project in a visit I did to their offices in June 2021. The second project I will refer to is the Bombay Street Project, the rebuilding of Bombay Street after 
being destroyed during the conflict. All materials for this project have been provided to me by the architect Ciaran Mackel, and insights of this by one of the members of the Bombay group project that is a recognised figure in both cooperative architecture and also Irish Language in Northern Ireland: the architect Seán Mackel. The first document is very important in explaining some of the decisions, and devices that were created to separate the areas of conflict particularly in the West of the city centre (both Catholic/Protestant communities). The second project is key in working across political barriers and working with a group that had members from both sides of the community. This group had the vision to rebuild memory and upgrade housing and recreate the street scape after its destruction. I believe to bring this very important work to light today, is key in understanding the positive interventions made in the city during the conflict period. Consequently, this key project sets an important precedent today.

Aldo Rossi introduces the concept of type in his book as a question rather than an answer: "It therefore seems clear that typological questions are important. They have entered into the history of architecture and arise naturally when urban problems are confronted" (Rossi 1988, 40). For him the idea of type is important in understanding the architecture of the city and locating what elements and types conform to it. It is essential to study the types of the past to understand the urban problems we confront today: "The concept of type became the basis of architecture, a fact attested to both by practice and by treatises" (Rossi 1988, 40). The idea of typology appears in Rossi's work as something necessary to classify: "We must be- gin with a question that opens the way to the problem of classification - that of the typology of buildings and their relationship to the city" (Rossi 1988, 35).

The second category of Rossi's book I am working with is the idea of memory. Rossi sees the city as something built by men over a period of time (Rossi 1988, 29). He also emphasizes the importance of urban artefacts, of history and of form. To describe what he means by artefact he refers as an example to Palazzo della Ragione in Padua, Italy. In this case the importance of the artefact and its relationship with the city is clear: the building's function can change but the form remains. In the case of Belfast many of these urban artifacts have been destroyed or new ones have been creating during The Troubles. By analysing the urban episodes (1-Political episodes 2-Construction and destruction of urban artefacts and elements that resulted because of this political episodes) through the dissection of the street in three section I will understand the relationship of these urban artifacts and episodes in each section of the street being analysed and the resultant spaces (in many cases spaces of defensive architecture but also of commemoration of different political events across the Strip).

I use Manuel de Manuel de Solà-Morales' approach for the construction of this street in Belfast as an "urban privileged city of conflict"- as a succession of episodes, data, dates, facts, details and events and interpretations and the opening of the street in this case to understand the lessons that can be drawn from a clear typological study of the street in three sections (Solà-Morales i Rubió 2008). Using his approach, I take the most urban episodes talking about Barcelona (Solà-Morales i Rubió 
$2008,10)$. "This is not so much a detailed account as a declaration of their importance to the present-day city, not an explanation of the genetic evolution of modern Barcelona(though it may to some extent to prove this)but an account of why Barcelona is as it is: illustrating which urban actions, projects and architects have made Barcelona what it is today". Transferring this concept of urbanism to Belfast is often difficult as conflict and division are difficult subjects, but by looking at those urban spaces we will be able to understand the typology of the street during and after division. And learning from the Falls we can investigate a much better space that resulted after 1998 , but a space that still has to be critically approached and analysed.

Using the concept of Strip, I can analyse and break down the street in different sections to understand how this post-conflict entity. It also looks at the positive elements of the resilience of the street, emphasizing the political importance of such a street not just in West Belfast but also in a European context. In this context of West Belfast and returning to SolàMorales (Solà-Morales i Rubió 2008, 26) "If in order to interpret the form of the city we try to reinvent a catalogue of spaces, the prototypes that we thought we have discovered have disappeared by the next day [...] A pavement, a glass façade, a wall, a ramp or a distant perspective interrupted by obstacles, a silhouette against the sky and a closed patio, bare, unfinished roads half-occupied by provisional pieces of furniture, a whole range of banal situations, of insignificant postcards, of series of 'peripheral' or 'unconnected' or informal' spaces are urban still-lifes if we look at them through the eyes of a painter [...]They are the syntagmata of the language of urban spaces". This quote really exemplifies the spaces along the Falls, spaces that often occurred suddenly as a result of both conflict, division and struggle. But at the same time by looking at them we can understand the typology of this street and its resilience and from the difficult understanding of these resultant spaces reflect on the urban typologies and look at how this street, and other divided street in this city or any other divided city. The street has evolved positively and developed over time at the heart of Irish language and culture revival, as a positive element of urban regeneration, but I will also be looking at some of the negative elements of both separation, neoliberal city and gentrification and sectarian division that still perpetuate in the interface spaces.

The two following sections of this paper will incorporate as explained both methods and discussion in each section of the aspects mentioned followed in a non-linear approach as fragments of the divided street in the contemporary city followed by a conclusion.

\section{THE FALLS (LOWER PART OF THE STREET, DIVIS FLATS AND THE WESTLINK)}

The Falls Road in West Belfast which runs from Divis Street to Andersonstown derives from the phrase túath na bhFál which in Irish means 'territory of the enclosures'. This street is in my view the most political street in Western Europe, certainly in West Belfast. The street known by the local by The Falls, has seen over 40 years of political struggle mainly focused on the Republican/ Irish community side of the conflict known as The Troubles. 
The meaning of words is interesting in expressing the importance of the neighborhood qualities of this part of the city, certainly the idea of how the territory of enclosures expresses the nature of the fabric originating from the $19^{\text {th }}$ Century, of terrace street that confirm the urban morphology of the city of Belfast. The chosen words are important because The Falls is a term commonly used by the locals there, if the term changes to the Lower Falls its meaning suddenly changes as this was the term used by the British Army during the conflict to refer to this section of the street which is still a problematic term for the catholic/Irish part of the community. There are two main elements that were constructed during the 1960's in that section of the street that changed forever it's traditional fabric with terrace houses: the construction of the Westlink Motorway that separated the West of the city from the city centre and the project of the Divis Flats (a 1960's typical modernist housing development, partially demolished and now only the Divis Tower remains). The result of this was a complete cut off of the West of the city, from the city centre removing all permeability in terms of street morphology built also creating a traffic infrastructure that changes and scars the city forever. The Divis Tower is the only remaining structure, that originally was going to move residents from poor quality terraced houses, but as the conflict escalated the area became important politically in the Irish/Catholic community in the West of the city. The last two floors and top of the existing tower were occupied by the British Army until 2005 to have a base from which to look at this area of the city, and further afield (sidfletcher666 2013).
The Irish architect Ciaran Mackel writes about this in his 2009 Cothaigh Fiaich lecture: "The Falls Road throughout the period of the conflict was our source of leisure, entertainment, business, commerce and culture. The Falls Road was, and still is, the thread that has both politically and culturally linked the hinterlands and heartlands that feed the concept of 'West Belfast' as much as the actual geographical place. Symbolically as our 'river' that flows from Twinbrook to Divis the Falls Road is our solid sea of living and doing business together and should be, our main street project. Government agencies and departments own or control much of the available lands along the road edge and a comprehensive plan which identifies projects for development within a broad holistic vision could be kickstarted by the opportunities such sites may afford" ${ }^{1}$. This sentence is exemplar in explaining the concept of place of what The Falls mean for its community, it flows like a river through the West of the City, having a concept of what it means to be from West Belfast, it was during the conflict the heart of the Irish Republican community, but today is part of the revival of the Irish community overall (a community not so much defined by faith in my view but by an inclusive culture). Having as MP for many years Gerry Adams, a key figure in Irish Politics in the West of the City but also hosting many Strong organizations like Forbait Feirste led by Jake MacSiacais to promote Irish culture but also the whole cross-community work with the West Belfast Corporation led until recently by Geraldine Mc Ateer.

1 Cothaigh Fiaich lecture $27^{\text {th }}$ November 2009 held at the Cultúrlann McAdam O Fiaich building, Falls Road Belfast delivered by Ciaran Mackel 
Ciaran Mackel writes about the paradox of the Irish Quarter revival: “The Gaeltacht Quarter is an astonishing paradox: on the one hand, it contains two out of the three most disadvantaged wards in the north of this island, and yet on the other it is also the site of an enormous outpouring of cultural innovation. This is a significant investment location close to major centres of commerce and communication with a convergence of assets that provide higher value and knowledge-based industries with opportunities to cluster and to enrich all of us by that process of clustering, exchange and 'cultural promiscuity"'2. On one hand you have this strong stage of Irish culture but in the interface areas between the Falls Road and the Shankhill Road social depravation and separation, exacerbated by 40 years of conflict and now really worsen by the Brexit of the UK from Europe. It is key to nurture positive relationships alongside cross-community groups to make sure the future of the West of the City is a common one for all.

To understand the construction of the Westlink it is important to go back to its history as an urban episode in the city: "The Belfast Urban Motorway was the name given to an ambitious scheme to build a continuous free-flow motorway around the city centre. Announced in 1964 but never built, the scheme would have had free-flow links to four motorways (M1, M2, M3, M4) which would themselves link to the rest of the planned motorway network" (History-Belfast 2021). As the conflict escalated in the 1970's the original plan was not constructed with the same ambition as originally planned: "This all unfortunately coincided

2 Ibid. with the start of the civil disorder known as the "Troubles" which began in 1969 and was at its worst during 1972 when one person was murdered approximately every 18 hours. This civil disorder was intense in the west of the city where repeated attempts to begin phase 1 had to be abandoned. [...] This new climate led to a full-scale review of the 1969 Transportation Strategy in 1975. It reported in 1976 and was itself the object of a public inquiry which dragged on into 1978. Its recommendations were to abandon virtually the entire scheme except for phase 1 , which was downgraded to a 2-lane dual-carriageway with two grade-separated junctions, two at-grade roundabouts and one at-grade traffic light-controlled junction. This became the A12 Westlink which opened in two stages in 1981 (M1 to Grosvenor Road) and 1983 (Grosvenor Road to M2)".

The resulting spaces were evident in the city fabric, it caused both fracture and disconnection including wasted problematic sites around this motorway but furthermore disconnecting the West of the city from the city centre. In this way The Troubles would be kept into areas of conflict (both Catholic and Protestant). An architecture of control of communities and disconnection of these communities from life in the city centre, still an issue evident today and exacerbating both social and sectarian issues. The Troubles concluded, and the spaces left over after the conflict are still evident in the fabric of the communities living in them.

The other aspect that became controversial of what happened around the Falls close to the city centre was the construction of the Divis complex, much of which now has been destroyed but with the Divis Tower remaining as a landmark of that period. While 1960's housing 


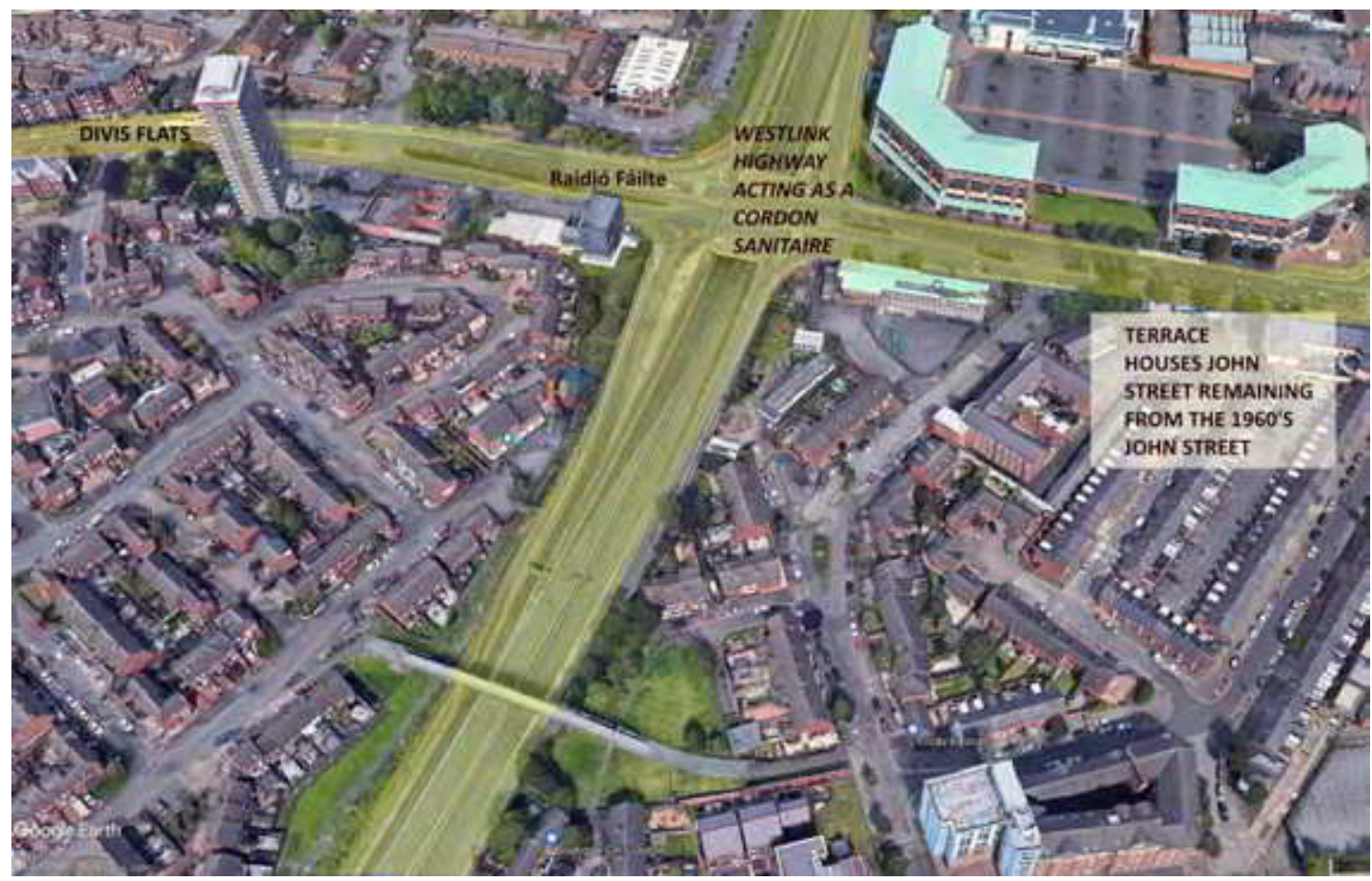

Fig. 1 Aerial view of West Belfast, at the left the 1960's Divis Tower, the Westlink highway is highlighted in yellow showing the cordon sanitaire built to separate the West of the City from the city centre. On the right remaining morphology of terrace houses (John Street, Barrack Street) giving an idea of how the morphology of this part of the city was before the construction of the Westlink. The building of Raidió Fáilte designed by architect Ciaran Mackel provides a modern and positive contemporary addition to this urban landscape at the Falls, also highlighting the importance of Irish speaking Radio for the local community. Image copyright Google Earth

often appears to be a solution to overcrowding housing and a utopic idea, developed by architects like Le Corbusier and in this case built at the bottom part of the Falls to remove residents from overcrowding conditions in existing terrace houses, this project became a very contentious political scheme as it was built in the late 60's. During the Troubles, the British Army built an observation post on top of the tower. This sort of architecture of conflict having a control tower to control the territory on the Falls Road and impacting on the communities living there. In this case the control happens from one side of the conflict to the other, but still these psychological barriers of control over space, both physical and psychological remain today on both sides of the communities.

Memory as a concept of architecture being an element of control. This psychological control of territory, of names, of two sides not trusting each other remains today in that part of the city. The architect Ciaran Mackel in his essay Impact of the conflict on public space and architecture A Troubles Archive Essay reflects the position of an architect and these spaces during the conflict: "Many architects simply ignored 


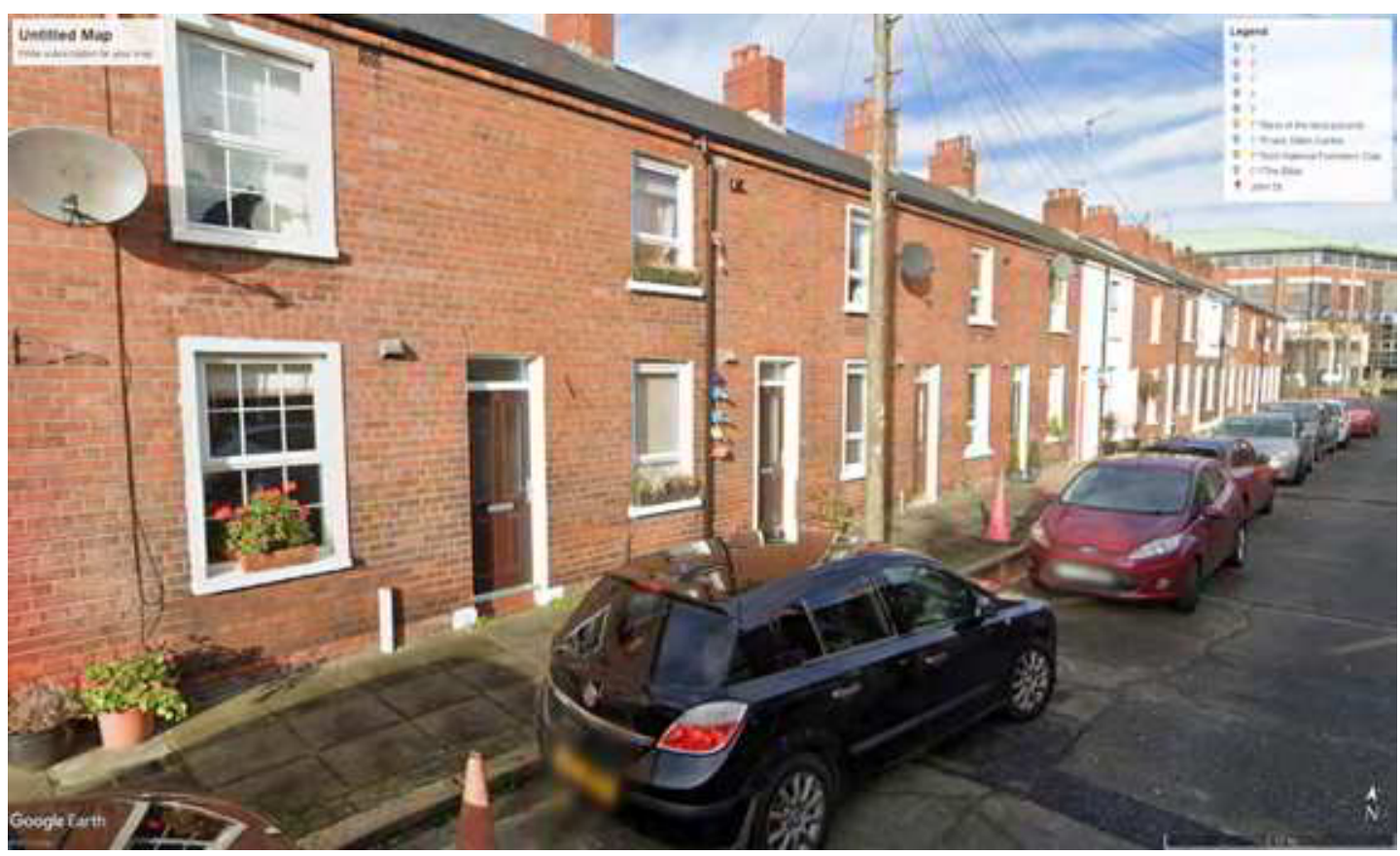

Fig. 2 Existing terrace streets in John Street, Barrack Street showcasing the urban morphology in and around the Falls Road before the Westlink and the Divis Flats were constructed. The urban morphology of these terrace houses now have disappeared partially due to demolition to construct these 1960's projects and also as result of the conflict. Image copyright Google Earth

the conflict and "got on with the job" as many of those did in the business and professional sectors. Many buildings though reflected the solid expression of the interface walls and security barriers. Public houses were built with no windows affording an external view and twin walls and fences surrounded the edge and isolated buildings. Police stations, court houses and security installations were wrapped by high walls and fences and imaged institutions under siege" (Essays | Troubles Archive 2021). In this part of the street we can see many of these defensive barriers, and objects left from the conflict, some of the barriers are physical such as the 'peace lines', the motorway, the buffer zones left in parts and pockets of The Falls but mainly we can see a defensive architecture that was thought to be temporary to control violence but is now a permanent manifestation that show exacerbated divisions led to the conflict. The memory of the old terrace streets that now exist in pockets next to the motorway, have removed the original low-density terrace streets that once were built across the whole of the Falls and that part of the city. Modern Urban Artifacts like the Divis Tower, or the Westlink substitute this old morphology, for a new street and artery that has been resilient to the conflict and has regenerated itself culturally. But the scars of the recent urban past have eroded the original urban morphology and instead of having these temporary measures like the highway and the 1960's utopic 
housing they have become testaments to a series of barriers, that should have not been left in the Falls after the Troubles ended.

This kind of defensive space which I will explain with more recent images is now the everyday territory that citizens live in. A territory of defensive spaces, 'peace lines', buffer zones, highly reliant on car usage, no permeable and disconnected physically from the city centre.

This new typological landscape cuts off people and their families from the West of the city with the city centre, and as shown only a few remaining streets retain that concept of memory that Aldo Rossi mentions as holding the Architecture of the City. The old architecture before the Troubles is somehow lost into this new space that whilst people are used to it since 1998, is not a normal space for everyday life. A space with devices that were left after division and conflict, is now normalized as a protective space, but is it really a protective space? or is it a space and territory that should indeed be challenged? The writer Vicky Cosstick who has written extensively about the walls writes: "But the interface areas are profoundly unhealthy places, places of disease,

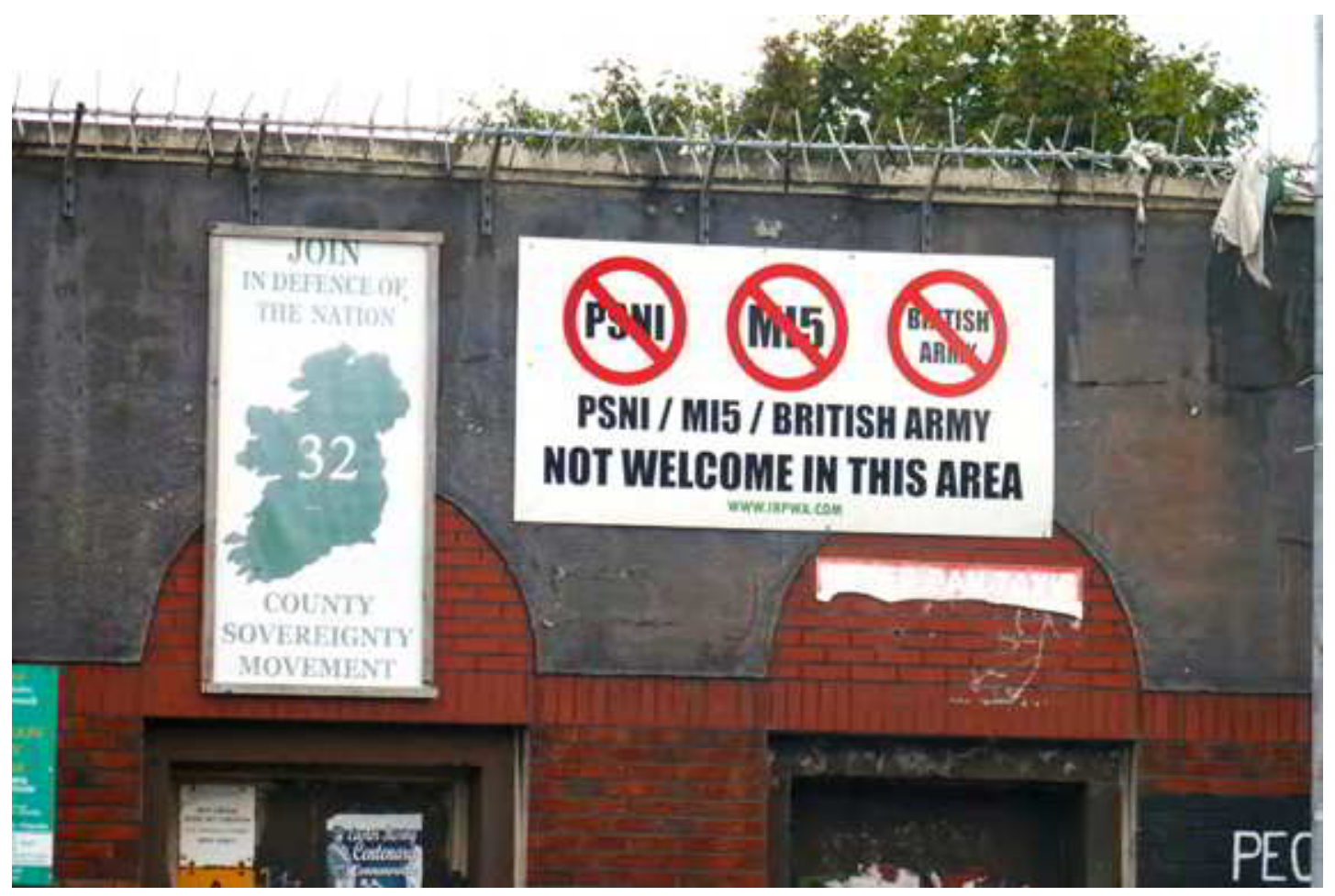

Fig. 3 Existing posters at the bottom left-hand side of the Falls Road, indicating for people to still join in deference of the Nation, and demarcating the territory and not welcoming to the community the PSNI (Police Service Northern Ireland), MI5 (Military Intelligence, Section five, counterintelligence agency of the British Government) and British Army. Image copyright Alona Martínez Pérez 
with the highest levels of mental and physical illness, addiction to illegal, prescription and non-prescription drugs, high levels of suicide and depression, in Northern Ireland [...]I have always seen the walls as a concrete manifestation of the unresolved legacy of the conflict, and like other persistent remnants of the conflict, curiously both visible and invisible at the same time" 3 .

I mentioned before that the conflict led to two kinds of barriers, one is defensive and

$\mathbf{3}$ http://www.belfastarchiveproject.com/frankiequinncordonsataire physical, and the other ones are psychological. The space was controlled during the conflict and as we can see in Figure 3 there are palisade security fencing on the top of the building, but most interestingly the signage in the area still indicates recent scars left over from the conflict. Certain sectors of British and Northern Irish society are not welcome here still; they also still welcome people in the area to join in defence of the nation (in this case a United Ireland). This photograph was taken by myself walking the area and is located near to the Divis Tower, where I mentioned earlier the

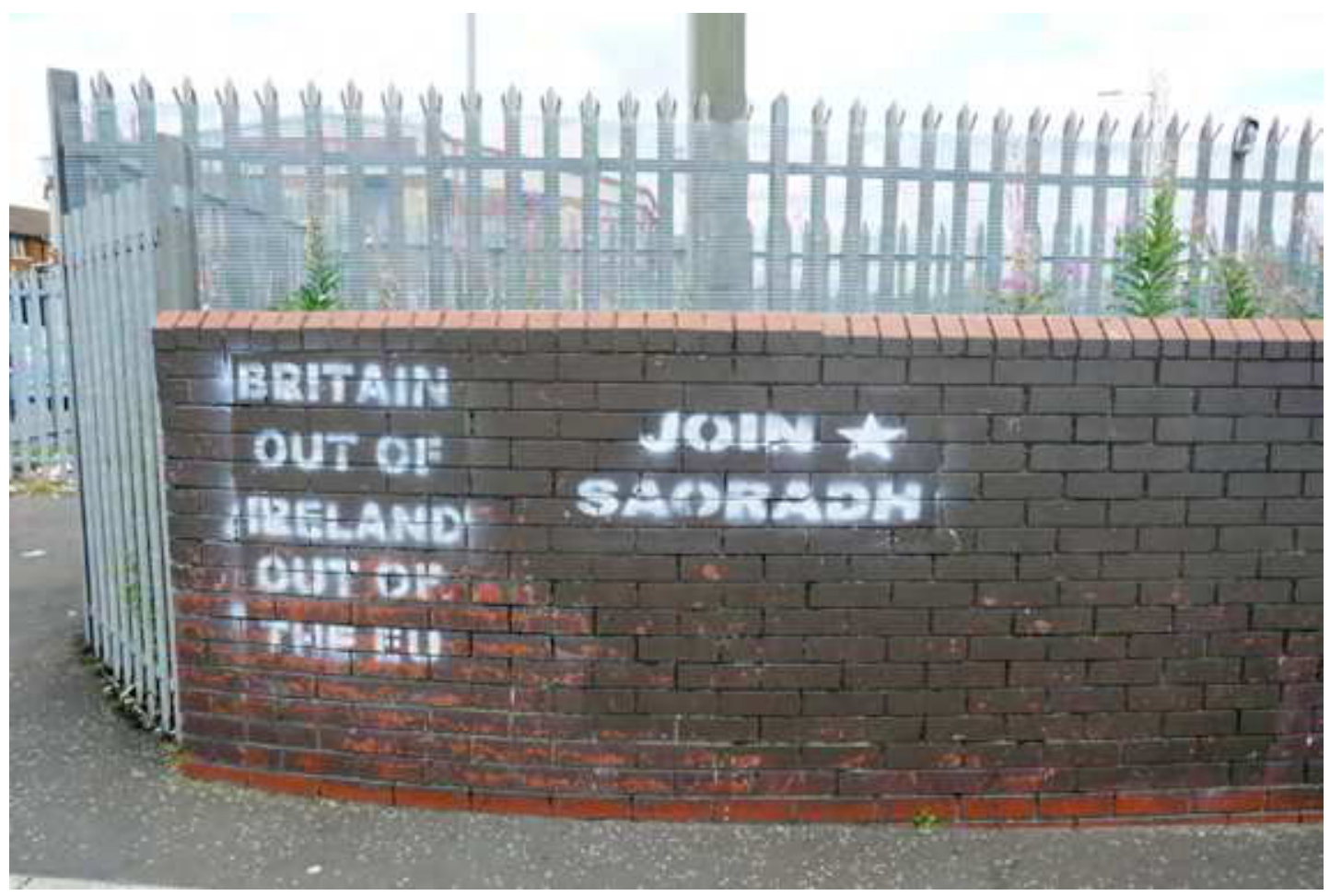

Fig. 4 In this image taken also at the bottom of the Falls, there are three defensive devices, 1- a Brick wall 2- A mesh device in front of the third layer of defensive barrier 3- Palisade security fencing behind brick wall. The wall is also used for a political message asking you to join Saoradh. The Revolutionary Republican Party, Saoradh, was established in 2016 and have been an integral part of working class, street politics since their formation. The party believes in the unification of Ireland, and as stated in the message Britain should be out of Ireland Image copyright Alona Martinez Perez 
top became a control point by the British Army until 2005. Clearly sixteen years after this control point was dismantled the issues remain on the ground.

When I mentioned defensive barriers in Figure 4 you can see three different barriers as explained. In the street where everyday people are walking, or children are playing in an environment of defensive architecture is the norm. This is an architecture not only of one layer of defensive space, but three layers of it the brick wall, the mesh in front and the most defensive metal barrier with thorns on top of it. The wall is also used as a political message to join a political Republican party Saoradah.

Now I will focus more on this kind of defensive space that is now part of the everyday lives of the community in this part of the street. In the next image we can see the contrast of two landmarks on the left Saint Peter's Cathedral, Belfast, the Catholic Cathedral built in 1860 that has survived the conflict with two tower landmarks on the left, next to the Divis flats. One the right a new kind of defensive space I took note of while walking, a defensive new space with palisade security fencing and mar-

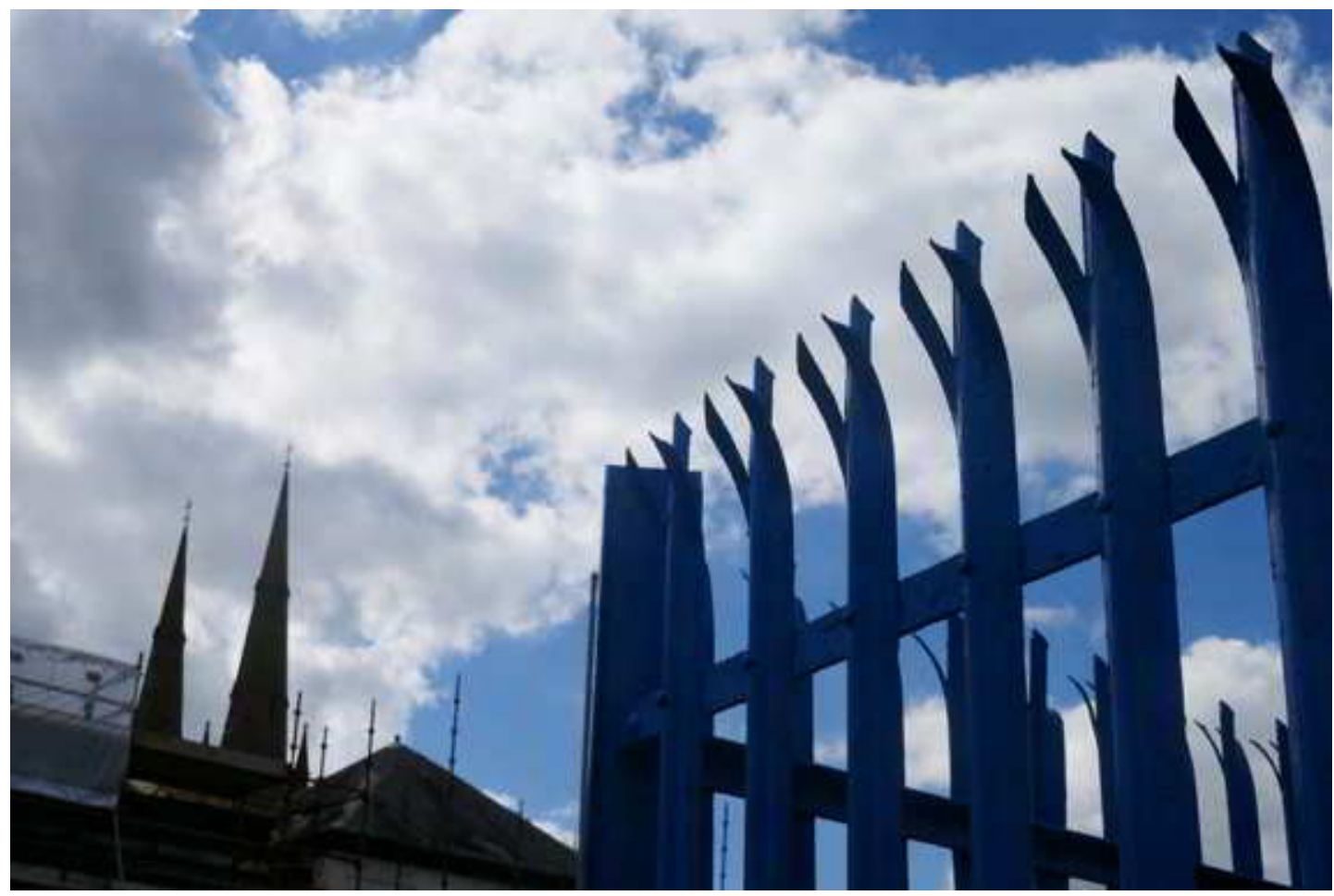

Fig. 5 In this image taken also at the bottom of the Falls, there are three defensive devices, 1- a Brick wall 2- A mesh device in front of the third layer of defensive barrier 3- Palisade security fencing. The wall is also used for a political message asking you to join Saoradh. The Revolutionary Republican Party, Saoradh, was established in 2016 and have been an integral part of working class, street politics since their formation. The party believes in the unification of Ireland, and as stated in the message Britain should be out of Ireland Image copyright Alona Martinez Perez 
king the territory today. This image contrasts the two different spaces that are in this part of the city, the space predating the conflict, a civic and engaged city space, with the new space that emerged during and after the conflict and remains here today.

The next space is a space I found while walking at the bottom at the Falls, it is a children playground space of which I took a photograph (Figure 6). There are some spaces for children to play, around the play areas there is a black fence, in front of that space a blue fence with palisade security fencing, and at the back of the space a concrete structure with another layer of barrier on top with more spikes. Over many years working in Belfast I was told, by residents that the peace lines offer protection for residents on each side of the wall. While I understand that point, and I respect that position, to have children playing, or indeed in a play space that has four layers of security devices is wrong from an architectural point of view but also from a moral one in my view. The space where we play and grow determines our relationship with that space for the rest of our lives. Looking at this from an outside point of view, twenty-five years after the Good Friday agreement these kinds of spaces for children and young people should be removed. Security devices are no longer required for children

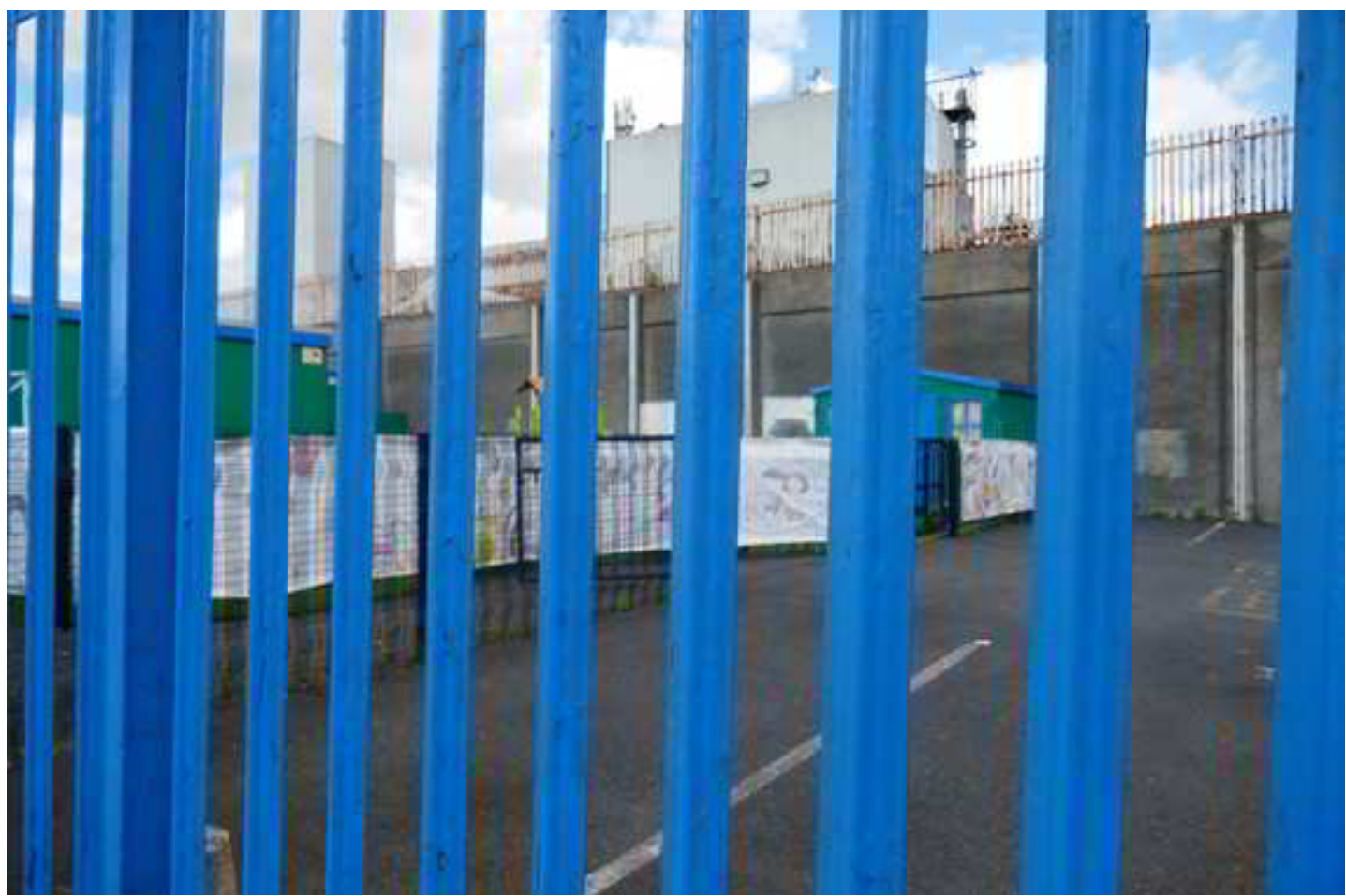

Fig. 6 In this image taken also at the bottom of the Falls, there are four defensive devices in a children playground area, 1- Palisade security fencing in blue 2- A black metal fence acting as a defensive barrier outside the children's' playground area 3- Brick wall in grey concrete 4- Metal fence on top of the wall. Image copyright Alona Martinez Perez 
play activities, and if they are present, serious questions should be asked as why they remain. Children should be allowed to grow up in an environment that is free of this kind of defensible spaces and architecture. An architecture that was created because of the conflict since the late 1960's, but sadly still remains today. Children's safety is one aspect of design and often these spaces have one layer of security (building access, access to premises), but this kind of space that appears alongside The Falls is a very defensive space with too many layers of security, that are no longer necessary

The American urbanist Mike Davis writes about this kind of defensible spaces in Los Angeles: "As city life grows more feral, the various social milieux adopt security strategies and technologies according to their means [...] To the extent that these security measures are reaction to urban unrest, it is possible to speak about a "riot tectonics" that episodically convulses and reshapes urban space" (Davis 2000, 364). Here he argues that when a city becomes wilder, security strategies appear everywhere, and what we see in the urban space is a new urban space that responds to this new feral city. To me this kind of space is what I describe in the examples I have analysed, a kind of architecture that is natural and normal in response to conflict and unrest, but after this conflict is over it has no place in the city any longer. Davis writes further in a US context about Latino Gangs and police response, but what I find interesting from his writings is when he mentions one of the Latino residents in the community: "As in a George Romero movie, working-class families now lock themselves in every night from the zombified city outside, As one resident told Los Angeles Times, "The bars remind me of being in a prison in my own house. But sometimes you do things you don't like in the interest of security. Yet such security might be a cruel illusion" (Davis 2000, 380).

I find that quote very powerful we imprison ourselves in our own domestic space for the sake of security, a self-inflicted security response to fear and security, the home and the public space become a new defensible space rather than a city where we can walk freely and a house where we feel safe, without needing defensible spaces (in the forms of walls, fences, or barriers) and I agree with Davis security is a cruel illusion. After the conflict is over this kind of defensive space (both in the domestic and public entity spaces), just separate and exacerbate sectarian divisions that already existed before the peace process. Today these barriers both physical but also psychological should be removed, if a shared future instead of a sectarian one is to be sought. Talking about schools Davis writes: "Schools also have become more like prisons. Even as per capita education has plummeted in many local school districts, scarce resources are being absorbed in fortifying school grounds and hiring more armed security police" (Davis 2000, 381). Obviously, he refers to LA here, but clearly all the money spent on fortification and security devices, would be better spent on education, in a place and in an architectural space where children do not grow normalising walls, fences, and security as normal part of their daily lives. A resultant space of violence is not normalised as the new norm. I know only too well, growing up myself in Bilbao (Basque Country) in the 1980's how violence and death can be normalised, and how that influenced my own experiences, and how these spaces now have been revitalised into 
much better spaces. These kinds of defensible spaces, both physical and psychological, have a profound effect in our perception of the city, it certainly did with me. The Bilbao I grew up in as a child is very different in my mind to the city I see today. It is a better city in many ways but for me the memories of the recent past remain intact in a painful way in my mind. Now that we have peace a new urban space should be sought, a space that is not like the spaces, and fragments I describe in this Paper.

As Belfast architect Ciaran Mackel writes:

"That challenge, I believe, is of crucial importance to how we address the blight and current desolate urban environment in our interface areas which are a huge swathe of potential public realm which have yet to be discussed in the context of city regeneration [...] The interface walls, the motorways, the provision of "enterprise" zones and urban infill planning strategies have all had drastic and negative impacts on connectivity in Belfast. The Shankill/Falls Wall is the longest standing "peacewall" in Europe, it is in places 10 metres high. [...] The interface walls are taller than most of the road frontages on most of the streets of the city including those active retail streets and they create unbearable enclosure ratios and a dismal urban experience. They are the crudest urban signatures, and the identity they portray engenders alienation and reinforces division" (Essays | Troubles Archive 2021).

These kinds of spaces remain today seven years after Mackel wrote that. In Figure 7 you can see a message board indicating that the space "is an alcohol-free area" and the sign of Gaeilge referring to the point that the message should be in Irish Language, the original language in Ireland, prior to English. In the same Figure 7 the so-called buffer zones left into the landscape between two areas appear across the whole length of the street scene. Figure 8 shows the fracture of the urban fabric caused by the Westlink, in this case at the bottom of the Falls with the city centre. Four lanes of traffic that are not necessary in a city the size of Belfast. Today in 2021 the highway remains a point of fracture between the West of the city and the city centre, a cordon sanitaire that was planned at the height of the conflict and remains in that part of the city. A clear vision should be implemented to remove this barrier and reconnect the West of the city to the city centre.

Currently if you want to walk from the Falls to the city centre you must go over a car dominated environment, a fractured city, a highway that was created clearly to separate the working-class areas from the West of the City to the city centre in mind, so the conflict will be concentrated in the areas of tension and protected from the city centre. The Westlink leaves a scar in the city that needs to be addressed by all parties, including city officials and the Westlink should be changed and removed to avoid Belfast being the most motorised city in Western Europe: "Belfast is even held to be the most car-dependent medium-sized city in Western Europe" (Ploger 2007, 18). In images 9 and 10 we can see the new landscape created because of the construction of the Westlink, originally created to act as a cordon sanitaire to stop the conflict from the West to the Centre, but today forty years later still fracturing the landscape of the street. It looks more like the landscape 

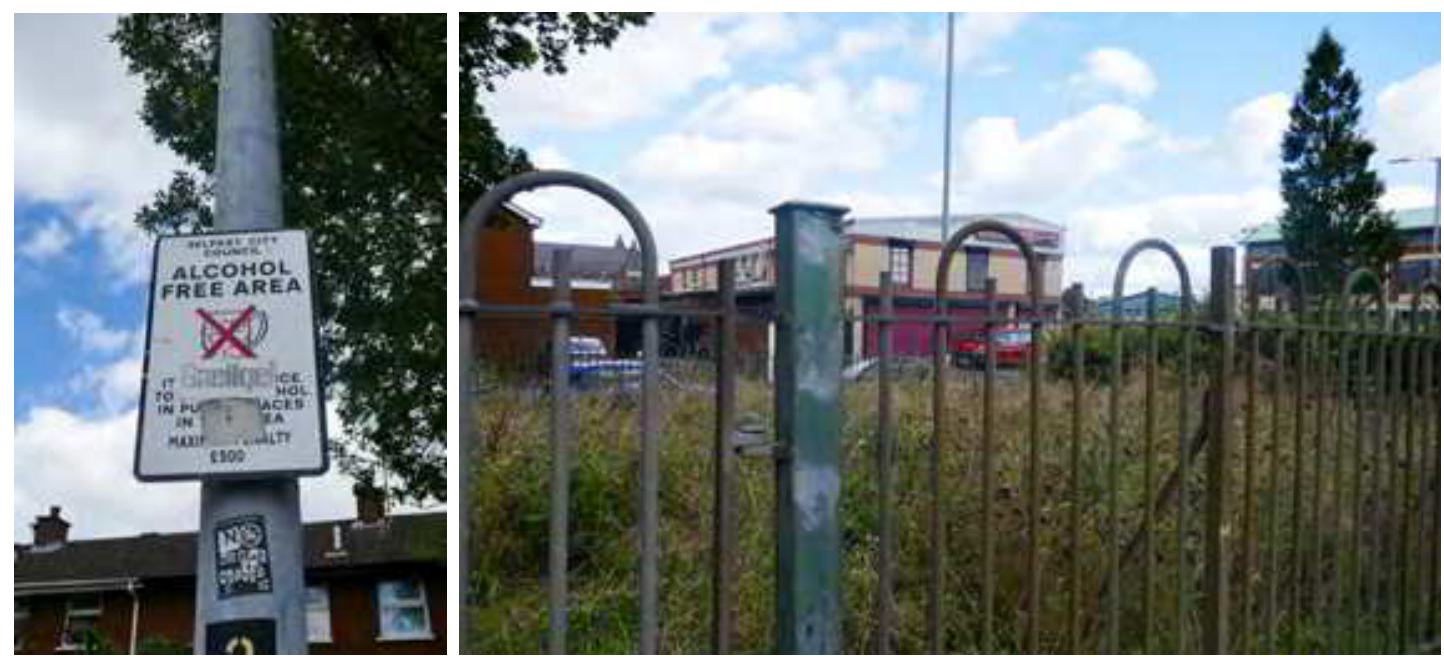

Fig. 7 Left Signage indicating the word Gaeilge, showing that the sign should be for the community in Irish not in English Right Buffer zone, empty space left after the conflict, many of these spaces stay in the interface areas Image copyright Alona Martinez Perez

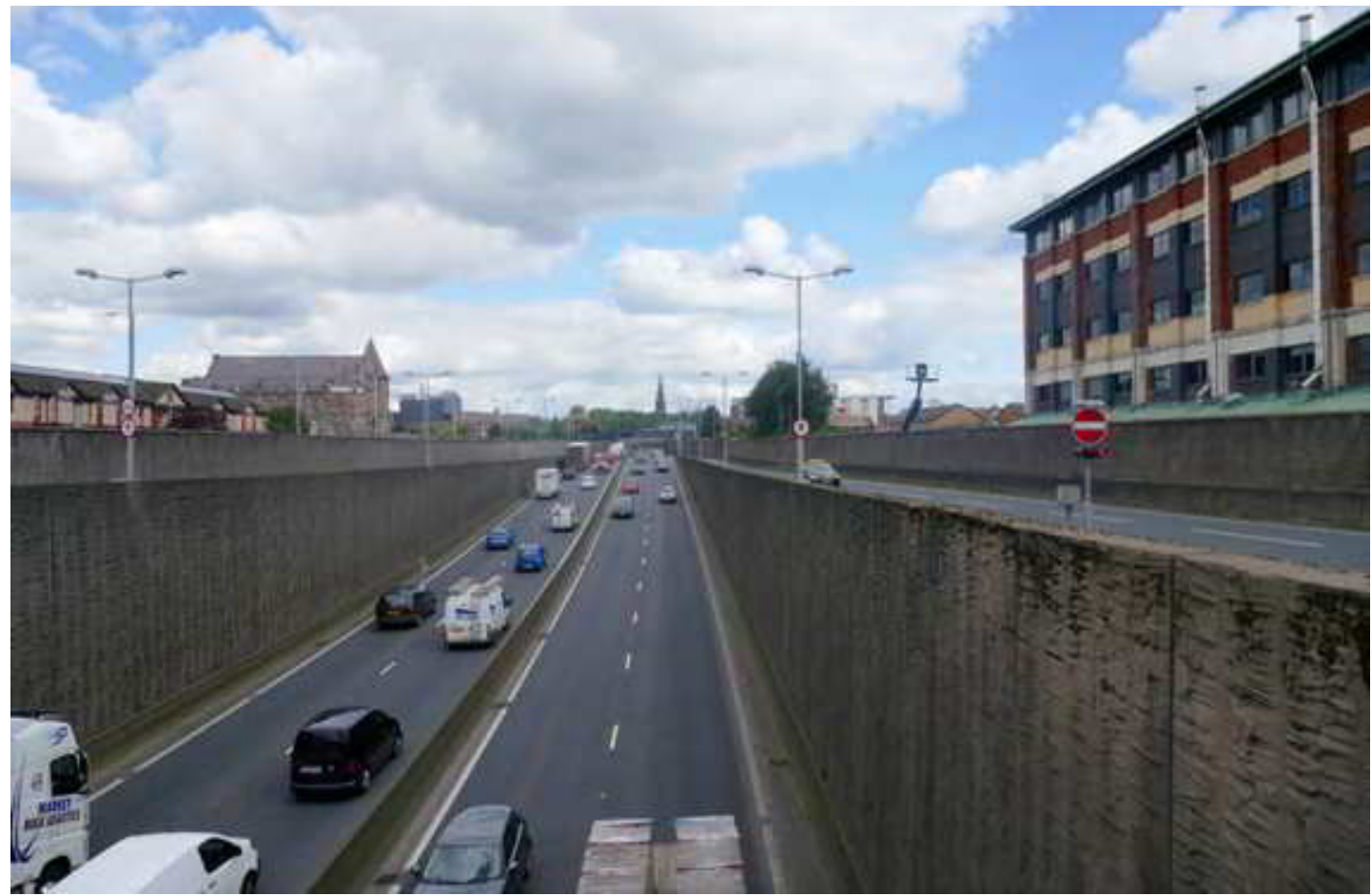

Fig. 8 This image shows the Westlink with four lanes of traffic breaking the urban morphology and connection of the West of the city and the city centre Image copyright Alona Martinez Perez 


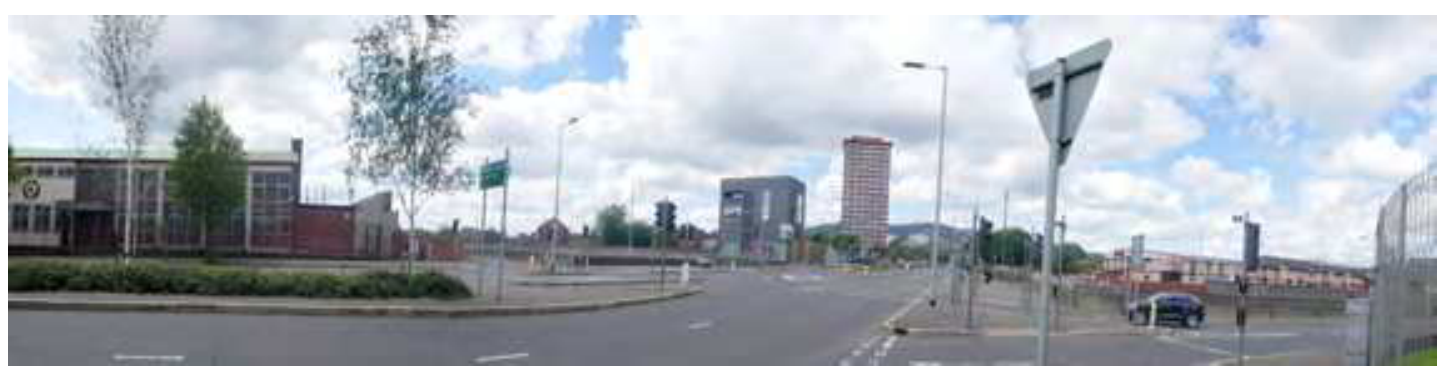

Fig. 9 In this image the street landscape is fractured by the Westlink motorway, a car-oriented environment full of car signs that does not welcome pedestrians. The building Raidió Fáilte designed by architect Ciaran Mackel provides a positive landmark and intervention in such a complex post-conflict, post 1960's urban landscape with the Divis Tower to the right Image copyright Alona Martinez Perez

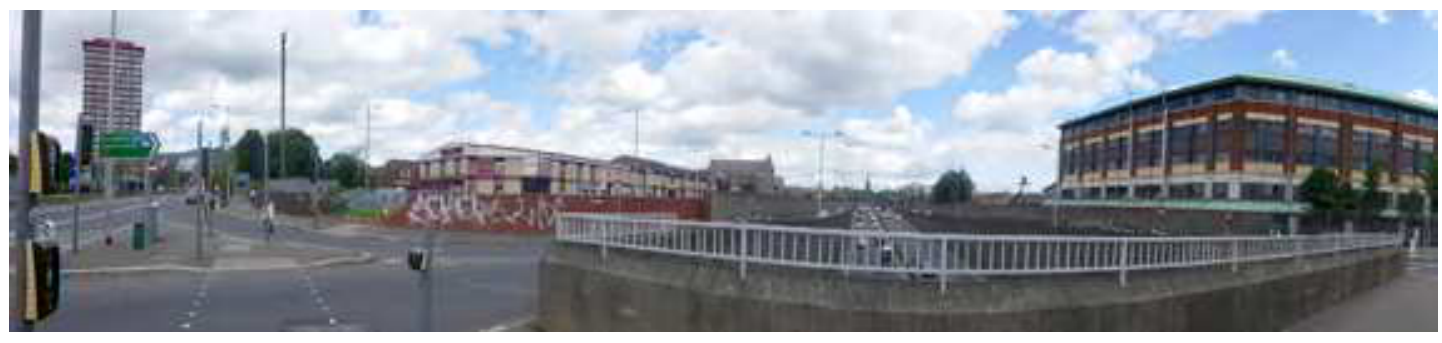

Fig. 10 In this the street landscape is fractured by the Westlink motorway, the urban barriers created in the street permeability and landscape is brutal, four lanes of traffic that we overlook where we walk from the Falls into the city centre. This cordon sanitaire created purposefully during the conflict remains today blighting the city's landscape. Image copyright Alona Martinez Perez

of a US city than a European one. For Venturi and Scott-Brown "the image of the commercial strip is chaos. The order in this landscape is not obvious. The continuous highway itself and its systems for turning are absolutely consistent" (Venturi, Scott Brown and Izenour 1996, 20) Using their work to analyse this urban environment the order of the Strip of the Falls is clearly provided by the signs (see Figures 9 and 10). The findings show that the car does not just rule the end of the Falls' environment, but the signs reveal a lesson, the communication over space and the new architecture in the street is defined by an architecture of signs and communication over space, an architecture related to cars and highways, rather than spaces directed towards people and pedestrians.
Physical Barriers and Bombay Street Project (architect Seán Mackel) as a key project to respond to the issues of urban fracture caused by conflict and memory

The Document is called "Government of Northern Ireland Future Policy on Areas of Confrontation. Second and Final Report of the Joint Working Party on Processions, etc" (Taylor 1971), I have copy number 43 and it was a Secret document of the Government of Northern Ireland. The document used was secret to the public for many years until it was released to the public recently. It states that is the Second (and Final) report of the Joint Working party on Processions. The document is directed in April 1971 by the Chairman to the Prime Minister of Northern Ireland the 
Honourable Rt. Hon. Brian Faulkner. They are a Working Party that constituted the group of the following individuals: Chairman is The Rt Hon J D Taylor (Minister of State at the Ministry of Home Affairs), and members are J G Hill Esq, Ministry of Home Affairs, KP Bloomfield Esq, Cabinet Secretariat, W Slinger Esq, Ministry of Community Relations, DJ Perham Esq, Ministry of Development, Major- General TH Acton CBE, Northern Ireland Headquarters, Assistant Chief Constable H Baillie, Royal Ulster Constabulary and A Hewins Esq, Office of the United Kingdom Representative in Northern Ireland. The Secretary was R A H Miller Es, Ministry of Home Affairs. The document in terms of architectural areas gives us two definitions "Areas of confrontation" and "Peace Lines". Areas of confrontation are defined as: "An area in which one district of more or less homogenous populations terms is contiguous with or readily accessible from another homogenous district of opposite loyalties, and where there has been since October 1968, or there is reason to apprehend, breaches of the peace" (Taylor 1971). The second definition Peace line "we mean any series of obstacles or barriers used to control movement between opposing districts of an area of confrontation such obstacles may be temporary or permanent, removed by day or in place for the twenty-four hours, manned or unmanned" (Taylor 1971). This document is now forty years old, and these definitions were used in a then secret government document at the height of the conflict. After mapping in the earlier section some of the architecture, and defensive spaces on the ground today, what to me seems two definitions created in 1971 to control urban space at the height of the conflict are still part of the city today. I cannot foresee that at the time this document was written that no one envisaged that the conflict was going to last so long, and all the years and casualties that followed afterwards. But what is revealing looking at this archival document, is that the West of the city, is still full of these areas defined in this forty-year-old document both areas of confrontation and Peace lines. Looking further into the document one questions how what originally was created to be a barrier to contain areas and parts of the conflict then becomes a permanent fixture of the city. Looking at this archival document is revealing about this point of temporary versus permanent structure and the nature of the barrier: "It is an ugly thing to see a barrier of this in a city in the United Kingdom [...]while it helped to reduce tension, its confirmed existence one moment longer than necessary creates an atmosphere of abnormality which is psychologically damaging [...] the abnormal can come to be taken for granted, and the search for fundamental solutions set aside for another day" (Taylor 1971). In this definition it contains two revealing points on one hand what defines as an atmosphere of abnormality then in 1971 and how these types of devices can be psychologically damaging in the long term. Contrasting this information with most recent data about these kinds of spaces today is revealing of the relationship of this kind of space and its psychological effects on the people living in new spaces born out of conflict. In a recent study in 2016 by Dr A. Maguire based at Queens University, Belfast talks about the relationship between these devices and its impact on mental health (Maguire, French and O'Reilly 2016, 845-854). She says: "Mental health among those living at peace lines is a major concern, with more than one in 
five individuals living there receiving anti-depressant medication compared to one in eight in the rest of the population [...]Even after taking into consideration other factors likely to affect mental health -including levels of deprivation, population density and crime- those living in peace line areas are 19 per cent more likely to be prescribed anti-depressant medication and 39 per cent more likely to be prescribed medication for anxiety, compared to those people living in other similar areas" (Morris 2016). I think in this case, the statistics of this study are critical in understanding the impact this architecture has in the communities living there. It is clear as part of the study that there is critical relationship between the physical environment and mental health of the residents living there. Dr Maguire states: "The only difference was the physical environment, so while the walls were erected for safety and security of residents they have a huge impact on mental health. This could be down to ongoing fear of violence or Troubles legacy. However, we ruled out legacy as a major cause as the impact on the younger generation was similar to those who had lived through the Troubles." (Morris 2016). However even though there is clear evidence of the effects on the walls and other devices on the people living there most residents still want the walls to be there: "However, a survey last year found that the number of people wanting their nearest peace line to remain in place has risen in recent years" (Morris 2016). So, even though the walls and these devices are damaging by those living near them, the surveys demonstrate that the number of residents that want the walls to remain are increasing rather than decreasing.

The archival document of the Working group I mentioned earlier refers to the walls in
1971 and it states: "The peace line is not only a physical barrier, its maintenance involves the deployment of substantial forces. This burden cannot be allowed to become permanent" (Taylor et al. 1971, 11) Those writing that document forty years ago foresaw these devices as clear physical barriers, they saw them as a burden and thought that they should never be allowed to become permanent. The sad reality is not only that they have become permanent features, but also that residents seem to have a protective nature as the survey of residents' state, that more people living nearby want the walls to remain (Morris 2016). However, the effects on mental health should be clear in terms of informing any policy of what to do with the peace lines in the future.

In terms of future policy, the conclusion of the study by Dr Maguire is clear: "In future studies, the environmental expression of segregation (walls, barriers, neighbourhood degeneration) needs to be taken into account and adjusted for to determine the mechanism underlying the association between segregation and health. In Northern Ireland, local policy makers are campaigning for the segregation barriers to be removed permanently. Although the current study cannot guide policy on whether the walls should remain or come down, their removal would provide an excellent opportunity for a natural experiment examining the impact of barrier removal on mental health" (Maguire, French and O'Reilly 2016, 70).

The impact of mental health in the postconflict environment in Northern Ireland is still staggering: "A 2011 study by Ulster University found that Northern Ireland has the highest recorded rate of post-traumatic stress disorder of any studied country in the world. 
The region also continues to have the highest suicide rate in the UK or Ireland, with about 18 suicides per 100,000 people in the population compared with nine suicides in England or eight in the Republic of Ireland, according to official government figures" (Belfast 2021).

It becomes clear that the relationship of those spaces and mental health is a clear relationship between space and a continuous segregation that instead of decreasing is increasing, both in terms of the barriers remaining and becoming more permanent, and with the relationship between these devices and the concept of protection rather than division.

In a recent study by a group of researchers at Ulster University on these hidden barriers their provides an insight to the current situation: "The deeply ingrained and embedded physical infrastructure of inter-community and intra-community division at the everyday level evidenced in our research (in addition to the inter-community tensions around housing in the past and present) does not sit comfortably with the macro approach to policy in Northern Ireland which fails to fully acknowledge or tackle head-on the lived realities of hidden barriers. Strategies for addressing conflict are written into many policy documents, and peacebuilding work is supported particularly in terms of local community groups funded to connect and work with "the other" community. [...] In other words, the reluctance to openly challenge the sectarian segregation that dominates inner-city social-housing, as was plainly evidenced in the 1970s and 1980s, still remains" (Coyles, Hamber and Grant 2021, 1-24).

On the afternoon of $15^{\text {th }}$ August 1969 forty-four of the sixty-five houses on Bombay Street were burned to the ground. During three days of riots throughout working class areas of Belfast ten people (both Catholic and Protestant), were killed, street barricades were erected, approximately 1500 Catholic families had to flee their homes and six hundred houses were badly damaged of which one hundred and seventy were beyond repair. Bombay Street is probably the most famed in the collective memory of those times.

By November 1969 it was clear that the City Council (who had given an undertaken to rebuild the street) had no interest in doing the work and indeed some councillors were in favour of leaving a 'no man's land' between the Falls and Shankill areas. In that context a small group of Irish language enthusiasts -who had just completed a cluster of houses on Belfast's Shaws Road-decided to undertake the work. They met with the former residents of the street and agreed to form a Housing Association and to commence building work immediately. Work commenced on $12^{\text {th }}$ December 1969 and keys to the first ten houses were presented to the local people in June 1970.

Here we can see an existing street being destroyed and removed as part of the conflict and in the middle of it the initiative of a group of activists that decided to work across boundaries in the communities to rebuild the houses in the heightened period of the conflict. It showcases how the importance of collective initiatives led by the architect Seán Mackel and the group, not just reconstructed the street but also rebuilt it to current modern standards raising the money, breaking barriers, and challenging the status quo.

The Architect Ciaran Mackel and son of Seán Mackel recalls the work of the men and activists that were part of the group: 


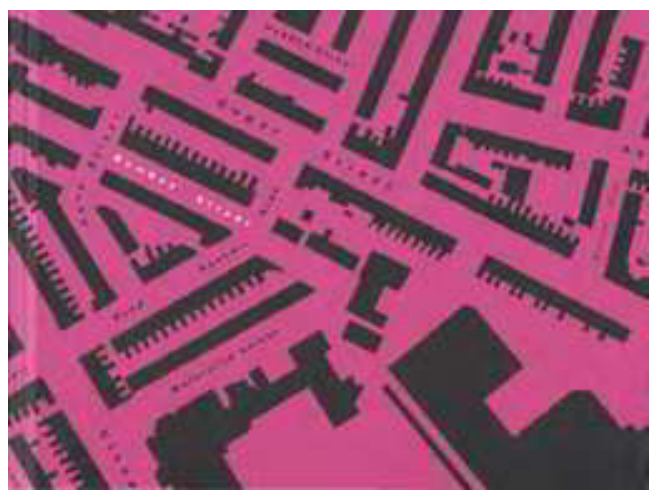

Fig. 11 Street pattern of Bombay Street a typical terraced street in Belfast located close to the Falls Road Image copyright Ciaran Mackel's archive

"As a fourteen / fifteen-year-old my weekends were then spent going to churches up and down the east coast, of Ireland, from Belfast to Dublin collecting money to help rebuild Bombay Street. Even as a teenager the disinterested gaze (of some artists and architects) was not enough: the subsequently learned and understood artist's conflict in the position between detachment and solidarity did not, for me, imply opposition to the other in our context but was an affirmation of place, the personal voice and of the contemporary world. Even as a youth I instinctively recognised the rebuilding of Bombay Street as a true sounding of the best aspects of my community - an instinct since borne by experience. The rebuilding of Bombay Street remains as one of the most moving, and greatest local examples of people doing things for themselves. It achieved the reconstruction of an entire community, and once people learned that they could build houses, create employment opportunities, and sustain communities they did

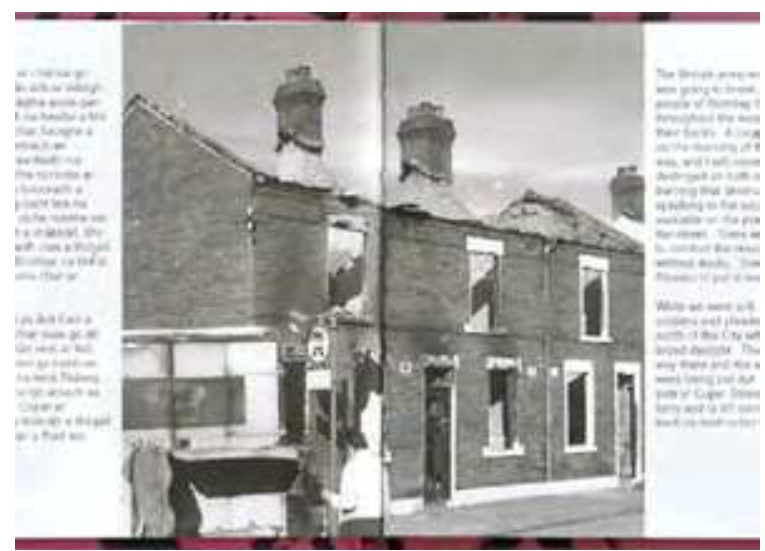

Fig. 12 Image showing the destruction of Bombay Street after the houses were burnt to the ground Image copyright Ciaran Mackel's archive

not stop. What followed included the Irish speaking schools of west Belfast, Garáiste an Phobail, the Whiterock Industrial Estate, numerous local co-operatives and not-for-profit enterprises and the work continues to this day with the Gaeltacht Quarter initiative. And what followed, for me, has been the fulfilment that comes from a centred satisfaction of seeing even the simplest, most ordinary project contributes to the improved quality of life for fellow citizens. Architecture is joyful. It is a pleasure enriched by the close working relationships afforded by clients, communities and the makers of buildings and places" (Mackel).

The selfless determination of men such as Séamus Napier, Seán Mackel, Ciarán Ó Catháin, Séamus Mac Seáin and Seán Mac Seáin, who formed the nucleus of that group, ought to be celebrated and recognised. They were deeply troubled by the plight of their neighbours and with compassion, rigour, and determination they emanated energy, generosity a belief 
in the community and provided practical and non-partisan community leadership on a voluntary basis.

The legacy of the group is undoubtedly the most important project of community cooperative across boundaries during The Troubles. Cross-community and determination at the highest level, normal people working across boundaries to pull through across community to allow people to take ownership of rebuilding their own houses, create opportunities for employment and to have collective ownership of their own housing. Seán Mackel's and his group's legacy was not just to recreate the street as it was, but to upgrade housing standards to meet the needs of the families that lost their houses from the ashes and give ownership of their own funding, construction and to recreate the memories of the street life before its destruction. Aldo Rossi defines the concept of memory as an important entity, to keep the concept of architecture. This exemplar is key to understand how people can be put over conflict, to build relationships to rebuild their own street against the backdrop of the ashes of the destruction that occurred here. Here the role of the architect gets seconded to the greater good of the community, and this is the legacy of Seán Mackel to his community and his group. As mentioned before sectarian divide and the consequences of it are showing that the divisions are not decreasing but increasing, hence why Bombay Street is a clear example of how today we can break across the divide, and recreate the street, remove boundaries and allow communities to take ownership, but for that leadership is required, and also a core belief in the community. If memory as an entity is lost, and street life is lost the environment of the community before the conflict is also lost. The architectural importance of Bombay Street and Seán Mackel's work is key to how Belfast should recreate the street life and move forward as an example of community architecture today.

His son Ciaran Mackel writes about the process of re-building the street "The re-imagined Bombay Street community is a story of self-sacrifice, self-reliance and self-realisation and remains an outstanding example of community activism. The group raised (in today's terms) $£ 2 \mathrm{~m}$ by voluntary subscriptions to meet the costs of 33 new homes of high technical standard, acquiring the title to all the lands, resurfacing and landscaping the street, encouraging local participation in the design of amenities and building confidence towards collective ownership. This all happened during two of the most turbulent years of the conflict and against a backdrop of government lethargy and procrastination" (Mackel).

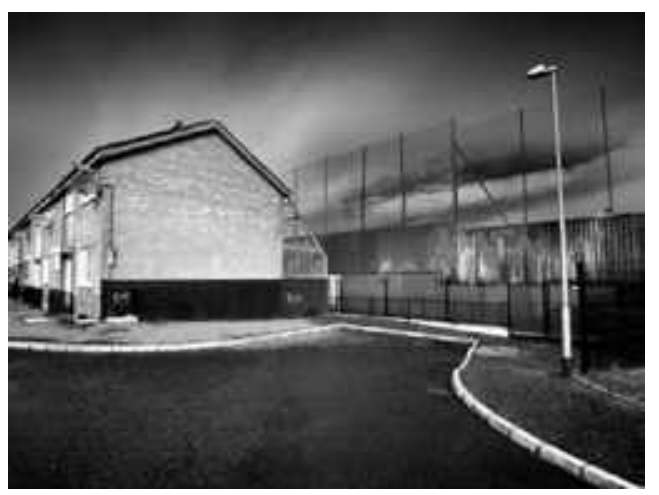

Fig. 13 This photograph shows the project developed by Seán Mackel recreating the street destroyed by the bombing in the two most turbulent of the Troubles, increasing technical standards and providing decent housing for families that lost all their houses as a result of the conflict. Image copyright Ciaran Mackel's archive 
The group wished to strengthen Bombay Street's pre-existing living patterns and indeed in a letter to the planning authority dated 22 February 1971:

"We understand that Cupar Street is being widened and would assume this will take place to the west side to remove the bad bend. In light of the present situation would it be possible to reconsideryour earlier proposals and permit re-development here for housing and shopping? This really is the only point of contact between Falls and Shankill where the housing was mixed. It appears unfortunate that Falls and Shankill will be redeveloped along parallel lines perpetuating the sectarian division of these two areas. Small though it is, this area does offer the possibility where we could co-operate with others from Shankill and with Belfast Corporation and Ministry to redevelop for housing and shops"

Seámus Napier, another member of the group was "Coming from a prominent Belfast legal family (his brother, Sir Oliver Napier, was founding leader of the Alliance Party), he possessed a high energy level and a remarkable versatility as devoted husband and father, lawyer, creative writer and historian" (The Irish Times 2008). The group worked tirelessly to rebuild Bombay Street and to promote Irish language as a tool for cross community importance selflessly. Napier was key into breaking boundaries across the boundaries that existed then: "He was also one of those who took part in the tortuous negotiations with the pre-1972 Stormont government,

4 This information has been provided by Ciaran Mackel to the author from his father's archive

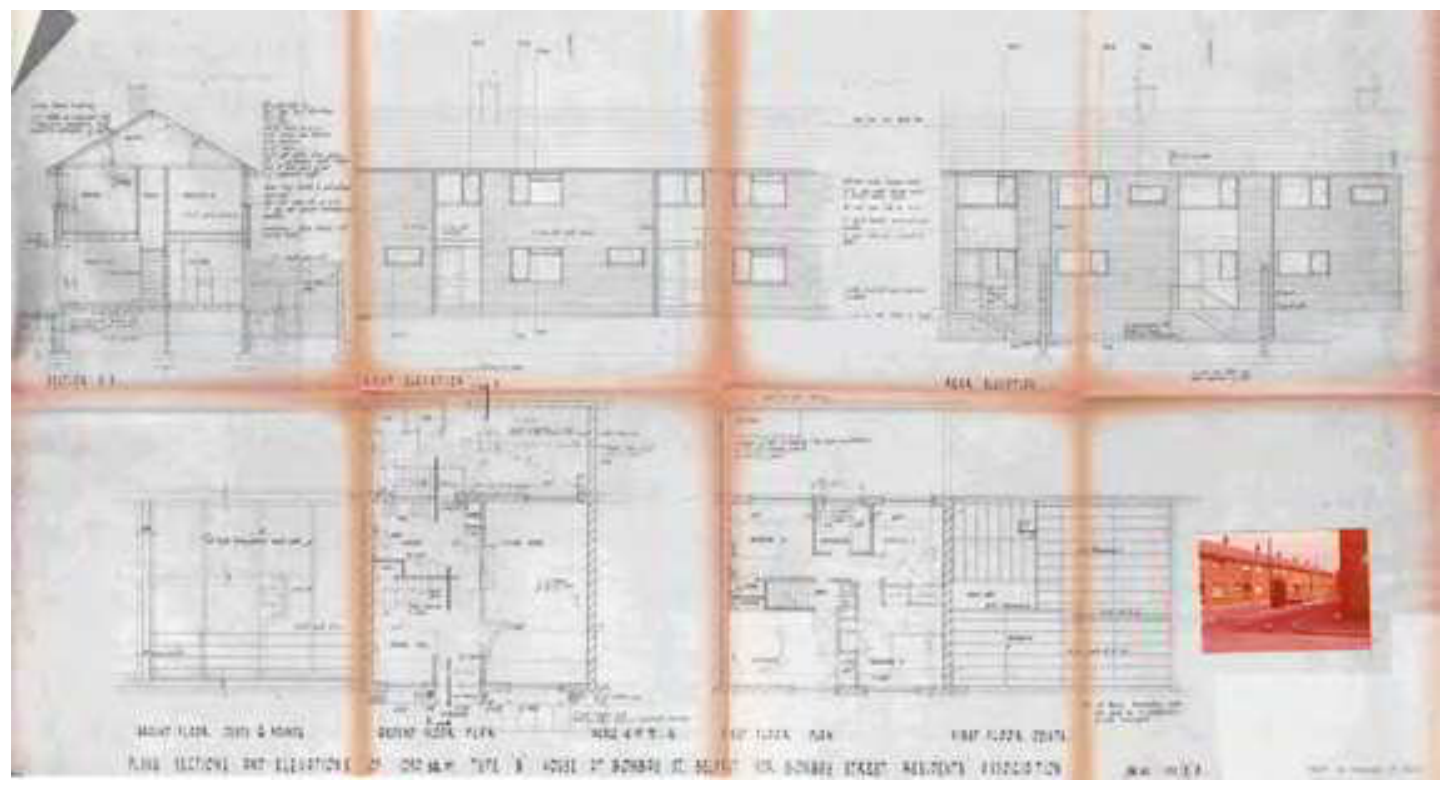

Fig. 14 In Image of the Bombay street project by Seán Mackel, showing technical standards improved, and different typologies of houses for residents. Image copyright Ciaran Mackel's archive 
leading to the establishment of the first Irish-medium primary school, Bunscoil Feirste" (The Irish Times 2008).

The urban reading and lessons are clear: the scheme was conceived as 'urban in-fill' and retained the street pattern and urban grain of the area; the dwelling depth matched the depth of the traditional terrace dwellings of 8 metres. The built form reflected the morphology, built fabric and material quality of the Clonard area, and the end terrace of six (now demolished), adjacent to the taller built form of the existing school, was designed as a taller block with a serrated upper storey and roof form which also read as bastion to an intended road connection back to the Shankill -a road that has never since been opened.

The scheme, as built, comprised nineteen 4 bedroom and fourteen 3-bedroom houses. Twelve houses had integral garages (eight of which had first floor living rooms), and 6 onstreetcar parking spaces were provided. The street (before 'shared-surfaces / shared-streets were de rigueur in the lexicon of residential developments) was rebuilt with a raised pedestrian piazza as play space. Then assistant City Planner in Belfast City Council -Gerald McSheffrey- subsequently chief architect with the Northern Ireland Housing executive (NIHE) and Dean of Architecture at MIT -was very supportive of the project and used it as model for a neighbourhood on which he was engaged in Chicago.

\subsection{CONCLUSIONS}

I met Seán Mackel in his house in June 2021, to do an interview about his work and the work of his legacy and his group in Bombay Street in 1969. He is not just one of the most humble and important architects in Ireland but his work in my view is of absolute importance then and now. This paper has showcased the effects that the destruction of housing and the postconflict space has today in the communities of the Falls Road. A space that is defensive, segregates rather than integrates, a space of voids, buffer zones and its connection to mental health and the communities living close to the interface areas. A space that was not designed to be there for longer than a few years but remains today forty years after the conflict. The work of Seán Mackel demonstrates what the Italian Architect Aldo Rossi would refer as the concept of memory, the legacy of the street as a key element of city life for its citizens. Streets that were destroyed because of the Troubles and never reconstituted again. So, Bombay Street is critical because it happened in the early 1970's is the tale of people and determination. It is also very relevant as it helped the community to heal and stitch both the urban and cultural bounds then, and as described in this paper it will be an exemplar project in regenerating and rebuilding the street that was destroyed, and then rebuilt but upgrading the technical standards of housing required.

For Rossi it is important to be able to have an element that is permanent and fixed: "Typology is an element that plays its own role in constituting form; it is a constant" (Rossi 1998, 41). Type is seen here as something that remains, that idea of permanence constituted in the architectural objects. If the objects present today are separating the West of the city from the rest of the city, offering a landscape of post-conflict city, clearly careful considera- 
tion as to what is the history of Belfast before that conflict needs to be re-considered. Bombay Street has all these ingredients to recreate the street that was destroyed, the memory that was lost because of conflict, and the power of the communities above the conflict that separate them, and instead of doing so it was built in ten months. The street lost is rebuilt, in a humble way and this is the legacy of learning from Bombay Street today. Bombay Street remains a constant, in a landscape of lost memory. If the city loses its memory, it loses its essence. As shown in this paper the street was lost and substituted for the Divis Flats, the highway, and a series of peace-lines that are not stopping but growing since the Good Friday Agreement. These spaces are not spaces for future shared-spaces, or spaces that we should indeed as architects and citizens be proud of. A whole generation is growing up here and normalising them, which I understand fully having grown up in Bilbao when conflict was at its height should never be normalised. Children must grow in a place without barriers, they are not part of the conflict that was over in 1998, so therefore why should they be in such a space? The visionaries like the architect Seán Mackel realised then that the city should be a simple street, a Belfast landscape that offers decent collective housing for all. The secret document I mentioned earlier contained a quote from Anthony Hewins Esq, Office of the United
Kingdom Representative in Northern Ireland who wrote as an outsider coming to Northern Ireland: "The word ghetto has been lightly used in the past. These proposals would give the name substance and would attract criticism from all over the world" (Taylor et al 1971, 28). Sadly, the proposals that the dissident member of the group writing this report wrote, conform the landscape of West Belfast today, and to move forwards the memory of what that street was, is key. To take Rossi he took history of the city to do a modern critique of functionalism in the 1960's, to learn from Bombay Street and the past is key, for Belfast to move forwards into the future.

\section{ACKNOWLEDGEMENTS}

This article is dedicated to my dear friend Ciaran Mackel and his father Seán Mackel for all the work that they have done in Belfast in Northern Ireland for their communities. I am grateful for all the help given to myself as a researcher and architect in the preparation of this work. I am also indebted to all the people I have met in Belfast on both sides of the community, and the insights and privilege that have been for me to be part of their history, that looking from a distance is also my own story of growing up in a post-conflict city. Thank you also to Paul Novakovic for the editing and corrections, and the two reviewers for their comments.

\section{REFERENCES}

Belfast, Siobhán Fenton in. 2021. "Mental

Health Problems the Hidden Legacy of the Troubles". The Irish Times. Accessed
October 15. https://www.irishtimes. com/news/health/mental-healthproblems-the-hidden-legacy-of-thetroubles-1.4005470. 
Coyles, David, Hamber, Brandon and Grant, Adrian. 2021. "Hidden Barriers and Divisive Architecture: The Role of "Everyday Space" in Conflict and Peacebuilding in Belfast". Journal of Urban Affairs, June, 1-24. doi:10.1080/0735216 6.2021.1930017.

Davis, Mike. 2000. Ecology of Fear: Los Angeles and the Imagination of Disaster. London: Picador.

'Essays | Troubles Archive'. 2021. Accessed September 30. http://www. troublesarchive.com/essays.

'FrankieQuinn-CordonSanitaireIntro'. 2021. Belfast Archive Project.

Accessed September 30. http:// www.belfastarchiveproject.com/ frankiequinncordonsataire.

'Gaeilgeoir and Advocate for People "of No Property"'. 2021. The Irish Times. Accessed November 3. https://www.irishtimes. com/news/gaeilgeoir-and-advocate-forpeople-of-no-property-1.910835.

'History - Belfast Urban Motorway and A12 Westlink - Northern Ireland Roads Site'. 2021. Accessed September 29. http://www.wesleyjohnston.com/roads/ belfasturbanmotorway.html.

Maguire, Aideen, Declan French, and Dermot O’Reilly. 2016. “Residential Segregation, Dividing Walls and Mental Health: A Population-Based Record Linkage Study". Journal of Epidemiology and Community Health 70 (9): 845-54. doi:10.1136/jech2015-206888.
Mackel, Ciaran. Essay "Rebuilding from the ashes Bombay Street, Belfast" provided by the author.

Martinez Perez, Alona. 2021. "Spaces of Absence in the European City: Stitching Urban Infrastructure to Contemporary Collective Life". Architecture and Culture, February, 1-10. doi:10.1080/20507828.2021.187 8762.

Martínez Pérez, Alona. 2016. The Architecture of the Periphery. Sheffield: The University of Sheffield (Phd Thesis).

Morris, Allison. 2016. "One in Five in Shadow of Peace Walls on AntiDepressants". The Irish News. March 17. http://www.irishnews.com/news/ northernirelandnews/2016/03/17/news/ one-in-five-in-shadow-of-peace-walls-onanti-depressants-453038/.

Ploger, Jorg. 2007. "Belfast City Report”. Monograph. London, UK: Centre for Analysis of Social Exclusion, London School of Economics and Political Science. December. http://sticerd.lse.ac.uk/case/.

Rossi, Aldo, et al. 1988. The Architecture of the City. Cambridge, Mass: MIT Press.

Rossi, Aldo, and Peter Eisenman. 1982. The Architecture of the City. Oppositions Books. Cambridge, Mass: MIT Press. sidfletcher666. 2013. Divis Flats Belfast. https://www.youtube.com/ watch?v=6yeBykVOppQ.

Solà-Morales i Rubió, Manuel de. 2008. Diez Lecciones Sobre Barcelona: Los Episodios Urbanísticos Que Han Hecho La Ciudad 
Moderna: Urbanistic Episodes That Have

Made the Modern City = Ten Lessons on

Barcelona. 2. ed. Barcelona: COAC, Collegi

d'Arquitectes de Catalunya.

Solà-Morales i Rubió, Manuel de, Frampton,

Kenneth and Ibelings, Hans. 2008.

A Matter of Things. Rotterdam: NAi

Publishers.

Taylor, John D et al. 1971. Government of

Northern Ireland Future Policy on Areas

of Confrontation. Second and Final Report

of the Joint Working Party on Processions.

Dr Alona Martinez Perez is a Senior Lecturer at the Leicester School of Architecture, De Montfort University. Originally from Spain (Bilbao, Basque Country) she trained as an architect in England and Scotland holding qualifications in both architecture and urban design. She has completed her PhD at the University of Sheffield with a scholarship award on the subject of "The Architecture of the Periphery" looking at the theory of the periphery in the European city, with a case study in Madrid. She won the PhD Conference bid for AHRA (Architecture and Humanities Research Association) at Plymouth University and has presented over 20 papers and conferences on peripheral issues. Previous roles include Lecturer in Architecture at Plymouth University (2013-2017) where she was March 1 Leader and Head of Subject for Professional Studies, Lecturer in Place making at the University of
Secret Government of Northern Ireland.

Gaeilgeoir and Advocate for People "of No Property"'. 2021. The Irish Times. Accessed November 3. https://www. irishtimes.com/news/gaeilgeoirand-advocate-for-people-of-noproperty-1.910835.

Venturi, Robert, Denise Scott Brown, and Steven Izenour. 2000. Learning from Las Vegas: The Forgotten Symbolism of Architectural Form. 17th print. Cambridge, Mass, The MIT Press.

Ulster (2009-2013) where she was fully responsible for all urban design teaching in the MSc of Planning and Property Development, tutor for architecture at the University of Dundee and a Research Director at the Geddes Institute for the project of cities and regions. Dr Martinez Perez also worked in practice for nearly a decade in both England and Scotland for a number of public and private sector clients and companies on a number of prestigious project ranging from $100 \mathrm{~K}$ to 40 million pounds in retail, hospitals, schools, hotels and master planning and continues to work as an architect in small projects. She is a Fellow of the Higher Education Academy in the UK, and holds a Postgraduate Diploma in Architecture and Urban Design, and a Master of Science in Urban Design from Edinburgh College of Art, and a degree of Architecture from Huddersfield University. 


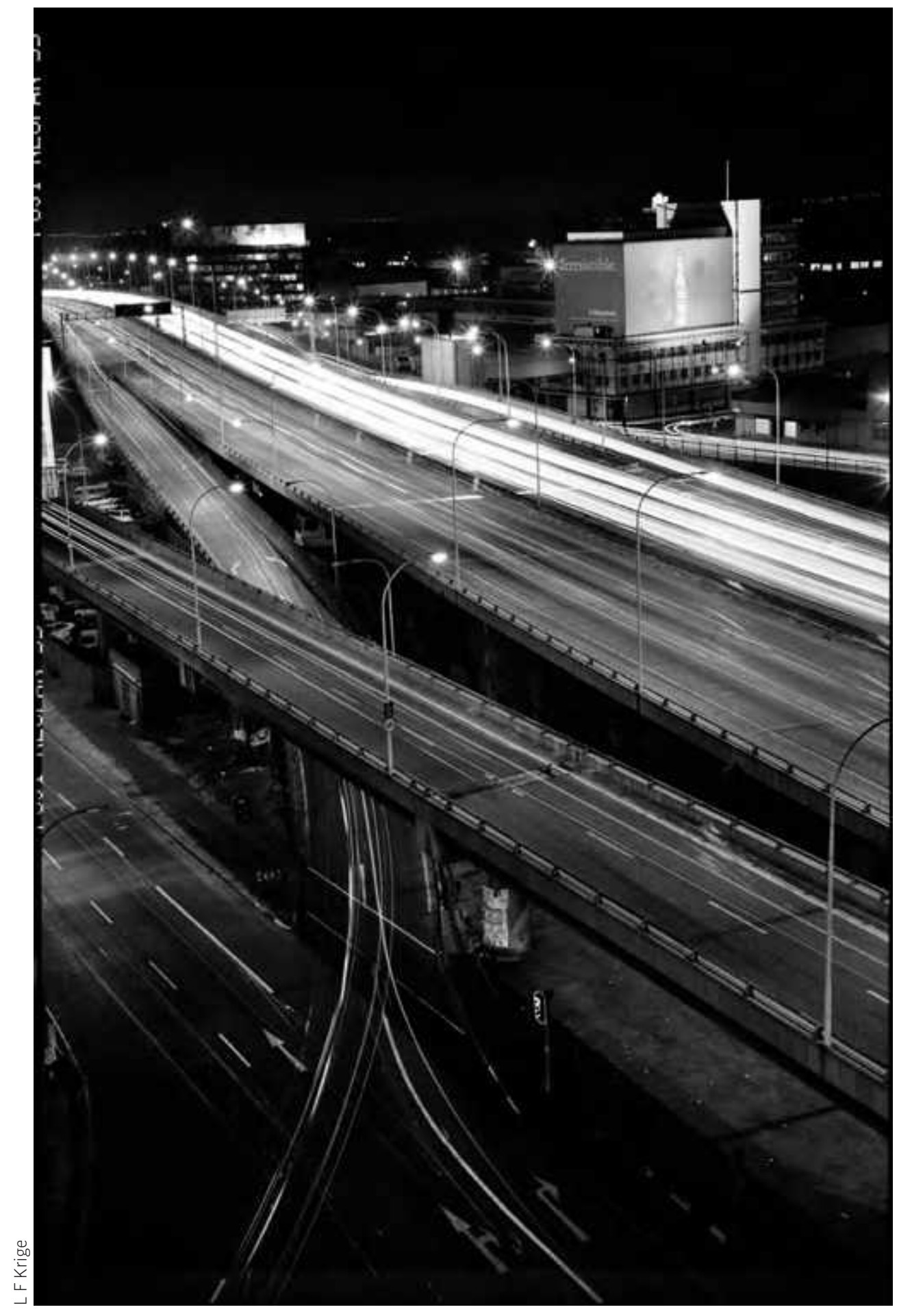

